Огляди літератури, оригінальні дослідження, погляд на проблему, випадок з практики, короткі повідомлення удК 616.37.-002.2-06:612.8

DOI 10.11603/1811-2471.2021.v.i1.11989

\title{
МОЖЛИВОСТІ ВИВЧЕННЯ ВЕГЕТАТИВНОГО СТАТУСУ ПРИ ХРОНІЧНОМУ ПАНКРЕАТИТІ В АМБУЛАТОРНІЙ ПРАКТИЦІ І НАУЦІ
}

\author{
@3. І. Сабат, Л. С. Бабінець
}

Тернопільський національний медичний університет імені І. Я. Горбачевського мОз України

РЕзЮмЕ. Вегетативна нервова система забезпечує пристосування організму до змін умов зовнішнього і внутрішнього середовищ. У сучасних умовах здоров'я розглядається як здатність організму адаптуватися до цих змін, а хвороба - як стрес і порушення адаптації. Вивчення вегетативного статусу при хронічному панкреатиті $\epsilon$ надзвичайно актуальним та інформативним для наступного ефективного лікування.

Мета - проаналізувати доцільність і методики визначення стану вегетативного статусу пацієнтів із хронічним панкреатитом, які використовуються в амбулаторній медицині та науковій практиці.

Основна частина. Хронічні захворювання органів травлення, зокрема хронічний панкреатит, значно поширені у структурі захворюваності внутрішніх органів. Залучення сегментарних і надсегментарних вегетативних структур до патологічного процесу значно ускладнює перебіг хронічного панкреатиту, у зв'язку з чим визначення стану вегетативної нервової системи та подальша вегетотропна корекція має важливе значення для підвищення ефективності лікування хронічної гастроентеральної патології загалом і хронічного панкреатиту зокрема.

Висновки. Визначення варіантів стану вегетативної нервової системи, а особливо наявності вегетативної дисфункції при хронічному панкреатиті повинно стати підґрунтям для диференційного підходу до регуляції стану вегетативної нервової системи, що приводитиме до ефективнішої та раціональнішої оптимізації функціонального стану підшлункової залози і нормалізації трофологічного статусу пацієнтів на ранніх стадіях захворювання.

ключовІ СловА: вегетативна нервова система; вегетативна дисфункція; хронічний панкреатит; методики вивчення вегетативного статусу; варіабельність серцевого ритму.

Вступ. Функціонування органів і систем, у тому числі шлунково-кишкового тракту, тісно пов'язане з психічним станом людини. Проблема співвідношення «психічного» $\mathrm{i}$ «соматичного» здавна $є$ актуальною в медичній науці і практиці. У стародавній Індії вважали, що негативні емоції - це перші щаблі до початку будь-якої хвороби. Давньогрецькі вчені розглядали людину як єдину систему і велике значення надавали характеру та темпераменту. Відомо, що стрес - це захисна реакція організму на будь-який сильний подразник і $\epsilon$ проявом адаптивного синдрому [1]. Сполучною ланкою між тілом і психікою є вегетативна нервова система (ВНС), вплив якої проявляється у вигляді вегетосудинних реакцій. Саме ВНС забезпечує пристосування організму до змін умов зовнішнього і внутрішнього середовищ. У сучасних умовах здоров'я розглядається як здатність організму адаптуватися до цих змін, а хвороба - як стрес і порушення адаптації [2-7].

Мета - проаналізувати доцільність і методики визначення стану вегетативного статусу паці$\epsilon$ тів із хронічним панкреатитом, які використовуються в амбулаторній медицині і науковій практиці.

Основна частина. Практично немає таких патологічних станів, у розвитку і перебігу яких не брали 6 участі вегетативні розлади. В одних випадках вони є чинниками патогенезу, в інших - виникають вторинно у відповідь на ушкодження різних систем організму [8]. Дисбаланс ВНС з активацією симпатичної та пригніченням парасимпатичної ланки є закономірною реакцією на стрес та одним із патогенетичних механізмів виникнення захворювань органів травлення, в тому числі панкреатиту [9]. На користь цього свідчать також випадки стресового хронічного панкреатиту (ХП), що почастішали на тлі складної ситуації в країні та світі. Відомо, що першою фазою зовнішньосекреторної діяльності підшлункової залози є мозкова фаза, механізм якої реалізується через центральну нервову систему шляхом умовних і безумовних рефлексів. На мозкову фазу впливають емоційний стан, біль тощо [10].

Особливостями вегетативної дисфункції (ВД) при захворюваннях шлунково-кишкового тракту $\epsilon$ те, що зміни відбуваються переважно на рівні центральної ланки вегетативної регуляції та мають полісистемний характер, тобто порушення в межах одного органа або системи органів призводять до порушення адаптаційних механізмів в цілому. Тому висновок про функціональний стан ВНС при захворюваннях органів травлення можемо зробити на основі оцінки вегетативної регуляції серцево-судинної системи [11-13].

До надсегментарних ВД неможливо застосувати принцип синдрому випадання або подразнення окремого вегетативного центру. Тому вони розглядаються як синдроми дезінтеграції, тобто порушення злагодженої роботи емоційних, вегетативних, моторних і ендокринних систем у забезпеченні гомеостазу [14]. 
Огляди літератури, оригінальні дослідження, погляд на проблему, випадок з практики, короткі повідомлення

Для виявлення ознак вегетативних порушень у пацієнтів гастроентерологічного профілю використовується опитувальник Вейна, який складається з 11 питань, на які хворі дають відповіді самостійно, оцінюючи свій стан у балах шляхом підкреслювання. Сума балів вище 15 свідчить про високу вірогідність наявності ВД.

Згідно з аналізом вітчизняної та зарубіжної літератури, у пацієнтів з ХП часто спостерігаються тривожно-депресивні розлади. Для їх виявлення рекомендують застосовувати опитувальники Спілбергера - Ханіна, Айзенка. Вони дозволяють оцінити рівень особистісної тривожності (ОТ, стійка індивідуальна риса), реактивної тривожності (РТ, мінлива, визначається у даній конкретній ситуації) та нейротизму (емоційна лабільність, збудженість, схильність до психопатології в емоційній сфері). Значення РТ і ОТ низькі - до 30 балів, середні - 3145 балів, високі - більше 45 балів. Нейротизм вважається маловираженим при отриманні 3-7 балів, помірним - при результаті 8-11 балів, вираженимпри результаті 12-15 балів, досить вираженим при результаті 16-18 балів, вкрай вираженим - при результаті 19-24 бали. Кількість балів менше 12 слід роцінювати як емоційну стабільність.

Стан ВНС оцінюємо за значеннями вегетативного тонусу, вегетативного забезпечення та реактивності. Під вихідним вегетативним тонусом (ВВT) розуміють відносно стабільні характеристики вегетативних показників у стані спокою. У забезпеченні тонусу беруть участь механізми, що підтримують метаболічну рівновагу, співвідношення між симпатичною і парасимпатичною системами. Раніше вважали, що симпатична і парасимпатична ланки ВНС функціонують за принципом противаг. Зараз доведено, що посилення функціонування одного відділу призводить до компенсаторного напруження іншого, що повертає функціональну систему до нормальних гомеостатичних показників. Гомеостаз, у тому числі вегетативний, не означає абсолютної сталості, а тільки встановлює межі, коливання в котрих не призводять до порушення функції.

Вегетативний індекс Кердо розраховується за формулою:

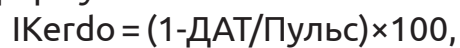

де IKerdo - вегетативний індекс, ДАТ - діастолічний тиск. тонусу:

Відповідно до стану ВНС виділяють 5 видів

1. Виражена парасимпатикотонія - переважання парасимпатичного тонусу, значення показника >-31;

2. Парасимпатикотонія - проміжний стан між нормою і парасимпатичним тонусом, значення від -16 до -30;
3. Норма - врівноваженість симпатичних i парасимпатичних впливів, значення від -15 до +15 ;

4. Симпатикотонія - проміжний стан між нормою та симпатичним тонусом, значення від +16 до 30;

5. Виражена симпатикотонія - переважання симпатичного тонусу, значення показника > +31 $[15,16]$.

Вегетативна реактивність (ВР) відображає здатність ВНС швидко реагувати на зовнішні і внутрішні подразники. Для визначення ВВТ і ВР серцево-судинної системи широко використовують кардіоінтервалографію. Метод базується на здатності синусового вузла реагувати на найменші вегетативні порушення з боку серцево-судинної системи. Це зумовлено не тільки особливостями іннервації синусового вузла, а й його зв'язками з корою головного мозку і підкірковими утвореннями ЦНС. Інформативним неінвазивним методом кількісної оцінки вегетативної регуляції на сьогодні визнано аналіз варіабельності серцевого ритму (ВСР) [17].

Серцевий ритм $€$ чутливим індикатором відхилень у вегетативному гомеостазі та може слугувати найпершою прогностичною ознакою виникнення багатьох захворювань, у тому числі ХП. Зміна ритму серця - універсальна реакція організму на будь-який вплив середовища. ВСР можна охарактеризувати як вираженість коливань частоти ЧСС по відношенню до її середньої [6]. Також завдяки ВСР можна визначити ступінь та можливості адаптаційних процесів $[4,5]$. Аналіз ВСР ґрунтується на розпізнаванні та вимірюванні часових проміжків між RR-інтервалами ЕKГ, побудові динамічних рядів кардіоінтервалів (кардіоінтервалограми) з подальшим аналізом отриманих числових рядів різними математичними методами [12]. На основі динамічного ряду інтервалів RR будується кардіоритмограма (КРГ) $[12,18]$. У КРГ кожен RR-інтервал поданий у вигляді стовпчика, висота якого відповідає тривалості цього інтервалу. Математична обробка КРГ дозволяє отримати ряд тимчасових, спектральних і геометричних показників, завдяки яким здійснюється об'єктивна оцінка стану ВНС, в тому числі їі симпатичного та парасимпатичного відділів. На сьогодні існує велика кількість методик аналізу ВСР, які можна об'єднати в три групи: методи часового аналізу, аналіз хвильової структури ритму серця (частотний аналіз), нелінійні методи аналізу ВСР (методи аналізу скатерограм) [19].

Спектр інструментальних досліджень, спрямованих на діагностику захворювань ВНС, на жаль, досі залишається обмеженим. У дослідженні вегетативного профілю широко використовується методика аналізу серцевого ритму, менш поширений 
Огляди літератури, оригінальні дослідження, погляд на проблему, випадок з практики, короткі повідомлення

метод викликаних шкірних вегетативних потенціалів (ВКВП) [20].

У 2001 р. дослідники Військово-медичної академії (Котельников С. А., Одинак М. М., Шустов Є. Б., Коваленко А. П.) і Санкт-Петербурзького державного університету (Ноздрачев А. Д.) розробили спосіб оцінки стану надсегментарних вегетативних центрів із виділенням інтегрального параметра - індексу ерготропної активності (IEA). Рівняння у перерахунку в бали має такий вигляд:

IEA $=0,01 \mathrm{Hc}-0,8 \mathrm{Ins}+17,25 \mathrm{Ca}-0,25 \mathrm{Bw}+0, \mathrm{lIK}+$ $0,45 a+16,4$,

де Нс - вміст кортизолу в периферійній крові (нмоль/л); Ins - вміст інсуліну в крові (пмоль/л); Са - вміст загального кальцію в крові (ммоль/л); Bw - маса тіла натще (кг); IK - вегетативний індекс Кердо (од.); Sa - особистісна тривожність за шкалою Спілбергера - Ханіна (бал).

Значення IEA в межах 50-60 балів відповідає стану ейтонії; більше 60 балів - вказує на переважання ерготропної активності надсегментарних вегетативних центрів; менше 50 балів - на переважання трофотропної активності [21, 22].

Загальновідомо, що важливим показником узгоджуваності регуляторних систем організму $\epsilon$ вегетативне забезпечення (В3) організму, під яким розуміють підтримку оптимального рівня функціонування ВНС під дією різноманітних навантажень (фізичних, психічних, емоційних, розумових тощо). При цьому слід враховувати фізичну тренованість, стать, психоемоційні особливості пацієнта. ВЗ оцінюється при виконанні активної кліноортостатичної проби (КОП), дані якої $є$ достатньо інформативними для визначення адекватності функціонування нейрогуморальних механізмів регуляції кровообігу.

ВД проявляється у зміні вегетативної реактивності і вегетативного забезпечення та викликає порушення обміну речовин (гіперхолестеринемію, диспротеїнемію, гіпер- і гіпоглікемію тощо), порушення системи згортання крові й фібринолізу [23]. У результаті ВД порушується іннервація внутрішніх органів, що зумовлює появу дискінезії ШКТ, порушення серцевого ритму і провідності, судинних дистоній. При пошкодженні і подразненні структур ВНС у різних органах виникають стереотипні морфологічні зміни (спазм судин, дистрофія), пов'язані з виділенням медіаторів (норадреналін, адреналін, серотонін), гормонів кори надниркових залоз, біологічно активних речовин. Ці гуморальні зміни своєю чергою посилюють вегетативний дисбаланс.

Методика проведення КОП полягає в оцінюванні чСС і АТ у горизонтальному положенні, а потім, під час переходу у вертикальне, - щохвилини протягом 10 хв.
Нормальна реакція на КОП визначається відсутністю скарг, підвищенням ЧСС на 20-40 \% від початкової, збільшенням систолічного (САT) і діастолічного (ДАТ) АТ не більше ніж на 5-15 \% (залежно від початкового). Зниження пульсового тиску в процесі ортостатичної проби не перевищує 50 \%. На 3-4 хвилині дослідження показники в практично здорових осіб повертаються до вихідних цифр.

Виділяють 5 патологічних варіантів реакції гемодинаміки на проведення КОП: із надмірним включенням симпатоадреналової системи (гіперсимпатикотонічний), із недостатнім включенням симпатоадреналової системи (асимпатикотонічний, гіпердіастолічний), змішані варіанти (симпато-астенічний, астеносимпатичний).

Гіперсимпатикотонічний варіант - більш різке підвищення САТ, ДАТ і пульсу, обличчя червоніє, хворий скаржиться на відчуття жару в голові (відображення гіперадаптації, пов'язаної з порушенням нервової регуляції).

Гіпердіастолічний варіант - ізольоване надмірне підвищення ДАТ при САТ, що не змінюється чи навіть зменшується, значно знижується пульсовий тиск і компенсаторно збільшується ЧСС (найбільш дезадаптивний варіант КОП).

Асимпатикотонічний варіант - САТ і ДАТ не змінюються або різко знижуються, ЧСС може залишатися нормальною або, при зниженні пульсового тиску більше ніж на 50 \%, компенсаторно збільшуватися (при значному зниженні САТ можлива непритомність).

Симпатоастенічний варіант - відразу після переходу у вертикальне положення відзначається нормальна або навіть гіперсимпатикотонічна реакція, потім на 3-6 хвилині спостерігається виражене зниження САТ і ДАТ, ЧСС зростає до 100 \%, при цьому часто відзначаються різка блідість, холодний піт, запаморочення, колапс.

Астеносимпатичний варіант -у перші хвилини ортостазу відзначають різке зниження САТ і ДАТ, різке підвищення ЧСС, потім виникає гіперсимпатикотонічна реакція, внаслідок якої АТ повертається до початкового рівня або вище. Визначення варіантів КОП у хворих на ХП може стати підґрунтям для диференційного підходу у регуляції стану ВНС, що, своєю чергою, приведе до ефективнішої та раціональнішої оптимізації функціонального стану підшлункової залози і нормалізації трофологічного статусу пацієнтів на ранніх стадіях ХП.

Висновок. Хронічні захворювання органів травлення, зокрема хронічний панкреатит, значно поширені у структурі захворюваності внутрішніх органів. Залучення сегментарних і надсегментарних вегетативних структур до патологічного процесу значно ускладнює перебіг хронічного панкреатиту, 
Огляди літератури, оригінальні дослідження, погляд на проблему, випадок з практики, короткі повідомлення

у зв'язку з чим визначення стану вегетативної нервової системи та подальша вегетотропна корекція мають важливе значення для підвищення ефективності лікування хронічної гастроентеральної патології загалом і хронічного панкреатиту зокрема. Визначення варіантів стану вегетативної нервової системи, а особливо наявності вегетативної дисфункції при хронічному панкреатиті, повинно стати підґрунтям для диференційного підходу у регуляції стану
BHC, що приводитеме до ефективнішої та раціональнішої оптимізації функціонального стану підшлункової залози і нормалізації трофологічного статусу пацієнтів на ранніх стадіях захворювання.

Перспективи подальших досліджень - на основі застосування представлених методик вивчити стан ВНС при хронічному панкреатиті і запропонувати диференційні програми для корекції виявлених порушень.

\section{ЛІТЕРАТУРА}

1. Некоторые аспекты стрессового панкреатита / Н. Б. Губергриц, А. Д. Зубов, П. Г. Фоменко, А. Е. Клочков // Сучасна гастроентерологія. - 2015. - № 1. - С. 81-84.

2. Степанов Ю. М. Показники варіабельності серцевого ритму в оцінюванні адаптаційних процесів і стресостійкості в гастроентерологічних хворих (використання новітніх технологій PRECISE-діагностики) / Ю. М. Степанов, Е. В. Зигало // Гастроентерологія. 2020. - № 2. - С. 113-123.

3. Тимощук О. В. Диагностика нарушений адаптации и стрессоустойчивости у детей с хроническим гастродуоденитом / О. В. Тимощук // Здоровье ребенка. 2016. - № 6 (74). - С. 108-112.

4. Марушко Ю. В. Показники варіабельності серцевого ритму в оцінюванні адаптаційних процесів / Ю. В. Марушко, Т. В. Гищак // Здоров'я України. - 2015. № 2. - C. 45-46.

5. Stress and heart rate variability: a meta-analysis and review of the literature / H. G. Kim, E. J. Cheon, D. S. Bai [et al.] // Psychiatry Investig. - 2018. - Vol. 15 (3). - P. 35-245.

6. Koo K. M. The effect of the type of physical activity on the perceived stress level in people with activity limitations / K. M. Koo, C. J. Kim // J. Exerc. Rehabilit. 2018. - Vol. 14 (3). - P. 361-366.

7. Stults-Kolehmainen M. A. The effects of stress on physical activity and exercise / M. A. Stults-Kolehmainen, R. Sinha // Sports Med. - 2014. - Vol. 44 (1). - P. 81-121.

8. Пшук Н. Г. Соматизированные депрессии в о6щесоматической практике: автореф. дисс. д-ра. мед. наук. - Харьков, 1996. -42 с.

9. Психосоматичні порушення у хворих із патологією шлунково-кишкового тракту: особливості клінічного перебігу та підходів до лікування / І. Г. Палій, С. В. Заїка, Н. М. Миршук, І. В. Чернова // Практикуючий лікар. - 2014. - № 2. - С. 49-56.

10. Коротько Г. Ф. Возвратное торможение панкреатической секреции / Г. Ф. Коротько // Вестн. клуба панкреатологов. - 2013. - № 4. - С. 5-13.

11. Шапошникова Н. Ф. Влияние адаптационных механизмов вегетативной нервной системы на формирование заболеваний желудочно-кишечного тракта и мочевыводящей системы у детей / Н. Ф. Шапошникова, А. Н. Давыдова // Вестник Волгоградского мед. университета. - 2016. - № 2 (58). - С. 119-121.

12. Величко О. Н. Анализ динамики вариабельности ритма сердца при длительном мониторировании / О. Н. Величко, О. М. Дацок // Радиотехника. - 2017. T. $188 .-$ C. $79-85$.
13. Зв'язки показника активності регуляторних систем Баєвського з параметрами варіабельності серцевого ритму / І. С. Флюнт, О. Б. Тимочко, Р. Ф. Гривнак [та ін.] // Медична гідрологія та реабілітація. - 2011. - Т. 9, № 2. - C. 1-7.

14. Вейн А. М. Лекции по неврологии неспецифических систем мозга: 3-е издание / А. М. Вейн. - Москва: МЕДпресс-информ, 2010. - С. 62-63.

15. Мельникова С. В. Вегетативный индекс Кердо: Индекс для оценки вегетативного тонуса, вычисляемый из данных кровообращения / С. В. Мельникова // Спортивна медицина (Україна). - 2009. - № 1-2. C. 33-44.

16. Петраш М. Д. Особенности вегетативной регуляции при воздействии повседневных стрессоров: возрастно-половой аспект / М. Д. Петраш, В. А. Гребенников // Мир науки. Педагогика и психология. - 2018. № 6 (6). - С. 104.

17. Леженко Г. О. Вегетативні дисфункції у дітей. Патогенез, діагностика і терапевтична тактика / Г. О. Леженко, О. Є. Пашкова // Дитячий лікар. - 2011. - № 4. C. 20-32.

18. Катастрофы мгновенного сердечного ритма в модели мультифрактальной динамики и по данным холтеровского мониторирования / А. П. Иванов, А. Н. Кудинов, Д. Ю. Лебедев, [и др.] // Математическое моделирование. - 2017. - Т. 29, № 5. - С. 73-84.

19. Editorial: heart rate variability and other autonomic markers in children / J. Billman, J. Sacha, B. Werner, P. Jeleń // Frontiers Physiol. - 2019. - Vol. 10. - P. 1265.

20. Одинак М. М. Методология инструментального изучения вегетативной нервной системы в норме и патологии / М. М. Одинак, Е. Б. Шустов, С. В. Коломенцев // Вестн. Росс. воен.-мед. акад. - 2012. - № 2 (38). С. $145-152$.

21. Котельников С. А. Индекс эрготропной активности - интегральный показатель состояния надсегментарных центров вегетативной регуляции / С. А. Котельников // Физиология человека. - 2003. - № 3 (29). С. 66-71.

22. Коломейцев С. В. Инструментальная оценка эффективности лечения надсегментарных вегетативных нарушений / С. В. Коломейцев, М. М. Одинак, Д. А. Мирная // Вестн. Росс, воен.-мед. акад. - 2012. № 3 (39). - С. 112-115.

23. Вегетативні дисфункції у дітей / В. Г. Майданник, О. І. Сміян, Т. П. Бинда, Н. О. Савельєва-Кулик. Суми: Сумський державний університет, 2014. -186 с. 
Огляди літератури, оригінальні дослідження, погляд на проблему, випадок з практики, короткі повідомлення REFERENCES

1. Gubergrits, N.B., Zubov, A.D., Fomenko, P.G., \& Klochkov, A.Ye. (2015). Nekotoryye aspekty stressovogo pankreatita [Some aspects of stress pancreatitis]. Suchasna hastroenterolohia - Modern Gastroenterology, 1, 81-84 [in Russian].

2. Stepanov, Yu.M., \& Zyhalo, E.V. (2020). Pokaznyky variabelnosti sertsevoho rytmu $v$ otsiniuvanni adaptatsiinykh protsesiv i stresostiikosti v hastroenterolohichnykh khvorykh (vykorystannia novitnikh tekhnolohii PRECISE-diahnostyky). Hastroenterolohiia - Gastroenterology, 2, 113123 [in Ukrainian].

3. Timoshchuk, O.V. (2016). Diagnostika narusheniy adaptatsii i stressoustoychivosti u detey s khronicheskim gastroduodenitom [Diagnostics of adaptation and stress resistance disorders in children with chronic gastroduodenitis]. Zdorovye rebenka - Child Health, 6 (74), 108-112 [in Russian].

4. Marushko, Yu.V., \& Hyshchak, T.V. (2015). Pokaznyky variabelnosti sertsevoho rytmu v otsiniuvanni adaptatsiinykh protsesiv [Indicators of heart rate variability in the assessment of adaptation processes]. Zdorovia Ukrainy - Health of Ukraine, 2, 45-46 [in Ukrainian].

5. Kim, H.G., Cheon, E.J., Bai, D.S., Lee, Y.H., \& Koo, B.H. (2018). Stress and heart rate variability: a metaanalysis and review of the literature. Psychiatry Investig., 15 (3), 235-245.

6. Koo, K.M., \& Kim, C.J. (2018). The effect of the type of physical activity on the perceived stress level in people with activity limitations. J. Exerc. Rehabilit., 14 (3), 361-366.

7. Stults-Kolehmainen, M.A., \& Sinha, R. (2014). The effects of stress on physical activity and exercise. Sports Med., 44 (1), 81-121.

8. Pshuk, N.G. (1996). Somatizirovannyye depressii v obshchesomaticheskoy praktike [Somatized depression in general practice]. Extended abstract of Doctor's thesis. Kharkov [in Russian].

9. Paliy, I.H., Zayika, S.V., Myrshuk, N.M., \& Chernova, I.V. (2014). Psykhosomatychni porushennia u khvorykh iz patolohiieiu shlunkovo-kyshkovoho traktu: osoblyvosti klinichnoho perebihu ta pidkhodiv do likuvannia [Psychosomatic disorders in patients with pathology of the gastrointestinal tract: features of the clinical course and approaches to treatment]. Praktykuiuchyi likar-Practitioner, 2, 49-56 [in Ukrainian].

10. Korotko, G.F. (2013). Vozvratnoye tormozheniye pankreaticheskoy sekretsii [Recurrent inhibition of pancreatic secretion]. Vestn. kluba pankreatologov-Bulletin of the Pancreatology Club, 4, 5-13 [in Russian].

11. Shaposhnikova, N.F., \& Davydova, A.N. (2016). Vliyaniye adaptatsionnykh mekhanizmov vegetativnoy nervnoy sistemy na formirovaniye zabolevaniy zheludochno-kishechnogo trakta i mochevyvodyashchey sistemy u detey [The influence of the adaptive mechanisms of the autonomic nervous system on the formation of diseases of the gastrointestinal tract and urinary system in children]. Vestnik Volgogradskogo med. universiteta - Bulletin of the Volgograd Medical University, 2 (58), 119-121 [in Russian].

12. Velichko, O.N., \& Datsok, O.M. (2017). Analiz dinamiki variabelnosti ritma serdtsa pri dlitelnom monitorirovanii [Analysis of the dynamics of heart rate variability

during long-term monitoring]. Radiotekhnika - Radio Engineering, 188, 79-85 [in Russian].

13. Flyunt, I.S., Tymochko, O.B., Hryvnak, R.F., Oliyarnyk, O.Ya., Romanskyi, R.Yu, \& Tkachuk, S.P. (2011). Zviazky pokaznyka aktyvnosti rehuliatornykh system Bayevskoho z parametramy variabelnosti sertsevoho rytmu [Relationships between the activity index of Baevsky's regulatory systems and the parameters of heart rate variability]. Medychna hidrolohiia ta reabilitatsiia - Medical Hydrology and Rehabilitation, 9, 2, 1-7 [in Russian].

14. Veyn, A.M. (2010). Lektsii po nevrologii nespetsificheskikh sistem mozga: 3-ye izdaniye [Lectures on the Neurology of Nonspecific Brain Systems: 3rd edn.]. Moscow: MEDpress-inform [in Russian].

15. Melnikova, S.V. (2009). Vegetativnyy indeks Kerdo: Indeks dlya otsenki vegetativnogo tonusa, vychislyayemyy iz dannykh krovoobrashcheniya [Kerdo vegetative index: An index for assessing vegetative tone, calculated from the data of blood circulation]. Sportyvna medytsyna (Ukraina) Sports Medicine (Ukraine), 1-2, 33-44 [in Russian].

16. Petrash, M.D., \& Grebennikov, V.A. (2018). Osobennosti vegetativnoy regulyatsii pri vozdeystvii povsednevnykh stressorov: vozrastno-polovoy aspekt [Features of autonomic regulation under the influence of everyday stressors: age-sex aspect]. Mir nauki. Pedagogika i psikhologiya - The World of Science. Pedagogy and Psycholo$g y, 6(6), 104$ [in Russian].

17. Lezhenko, H.O., \& Pashkova, O.Ye. (2011). Vehetatyvni dysfunktsii u ditey. Patohenez, diahnostyka i terapevtychna taktyka [Autonomic dysfunction in children. Pathogenesis, diagnosis and therapeutic tactics]. Dytiachyi likar-Pediatrician, 4, 20-32 [in Ukrainian].

18. Ivanov, A.P., Kudinov, A.N., Lebedev, D.Yu., Mikheyev, S.A., Tsvetkov, V.P., \& Tsvetkov, I.V. (2017). Katastrofy mgnovennogo serdechnogo ritma $v$ modeli multifraktalnoy dinamiki i po dannym kholterovskogo monitorirovaniya [Instant heart rate catastrophes in the multifractal dynamics model and according to Holter monitoring data]. Matematicheskoye modelirovaniye - Math Modeling, 29, 5, 73-84 [in Russian].

19. Billman, J., Sacha, J., Werner, B., \& Jeleń, P. (2019). Editorial: heart rate variability and other autonomic markers in children. Frontiers Physiol., 10, 1265.

20. Odinak, M.M., Shustov, Ye.B., \& Kolomentsev, S.A. (2012). Metodologiya instrumentalnogo izucheniya vegetativnoy nervnoy sistemy v norme i patologii [Methodology for instrumental study of the autonomic nervous system in health and disease]. Vestn. Ross. voyen.-med. akad. Bulletin of the Russian Military Medical Academy, 2 (38), 145-152 [in Russian].

21. Kotelnikov, S.A. (2003). Indeks ergotropnoy aktivnosti - integralnyy pokazatel sostoyaniya nadsegmentarnykh tsentrov vegetativnoy regulyatsii [The index of ergotropic activity is an integral indicator of the state of the suprasegmental centers of autonomic regulation]. Fiziologiya cheloveka - Human Physiology, 3 (29), 66-71 [in Russian].

22. Kolomeytsev, C.B., Odinak, M.M., \& Mirnaya, D.A. (2012). Instrumentalnaya otsenka effektivnosti lecheniya nadsegmentarnykh vegetativnykh narusheniy [Instrumental assessment of the effectiveness of treatment of suprasegmental autonomic disorders]. Vestn. Ross. voyen.-med. 
Огляди літератури, оригінальні дослідження, погляд на проблему, випадок з практики, короткі повідомлення akad. - Bulletin of the Russian Military Medical Academy, 3 (39), 112-115 [in Russian].

23. Maydannyk, V.H., Smiyan, O.I., Bynda, T.P., \& Savel-

yeva-Kulyk, N.O. (2014). Vehetatyvni dysfunktsii u ditey [Autonomic dysfunctions in children]. Sumy: Sumskyi derzhavnyi universytet [in Ukrainian].

\section{ВОЗМОЖНОСТИ ИЗУЧЕНИЯ ВЕГЕТАТИВНОГО СТАТУСА ПРИ ХРОНИЧЕСКОМ ПАНКРЕАТИТЕ В АМБУЛАТОРНОЙ ПРАКТИКЕ И НАУКЕ}

\section{3. И. Сабат, Л. С. Бабинец \\ Тернопольский национальный медицинский университет имени И. Я. Горбачевского МОз Украины}

РЕзЮмЕ. Вегетативная нервная система обеспечивает приспособление организма к изменениям условий внешней и внутренней среды. В современных условиях здоровье рассматривается как способность организма адаптироваться к этим изменениям, а болезнь - как стресс и нарушение адаптации. Изучение вегетативного статуса при хроническом панкреатите является чрезвычайно актуальным и информативным для последующего эффективного лечения.

Цель - проанализировать целесообразность и методики определения состояния вегетативного статуса пациентов с хроническим панкреатитом, которые используются в амбулаторной медицине и научной практике.

Основная часть. Хронические заболевания органов пищеварения, в частности хронический панкреатит, широко распространены в структуре заболеваемости внутренних органов. Вовлечение сегментарных и надсегментарных вегетативных структур в патологический процесс значительно осложняет течение хронического панкреатита, в связи с чем определение состояния вегетативной нервной системы и дальнейшая вегетотропная коррекция имеют важное значение для повышения эффективности лечения хронической желудочно-кишечной патологии вообще и хронического панкреатита в частности.

Вывод. Определение вариантов состояния вегетативной нервной системы, особенно наличия вегетативной дисфункции при хроническом панкреатите, должно стать основой для дифференцированного подхода в регуляции состояния вегетативной нервной системы, что приведет к более эффективной и рациональной оптимизации функционального состояния поджелудочной железы и нормализации трофологического статуса пациентов на ранних стадиях заболевания.

КЛЮЧЕВЫЕ СЛОВА: вегетативная нервная система; вегетативная дисфункция; хронический панкреатит; методики изучения вегетативного статуса; вариабельность сердечного ритма.

\section{POSSIBILITIES OF VEGETATIVE STATUS STUDYING AT CHRONIC PANCREATITIS IN OUTPATIENT PRACTICE AND SCIENCE}

\section{Horbachevsky Ternopil National Medical University}

SUMMARY. The autonomic nervous system ensures the body's adaptation to changes in external and internal environments. In modern conditions, health is seen as the body's ability to adapt to these changes, and illness - as stress and maladaptation. The study of vegetative status at chronic pancreatitis is extremely relevant and informative for the next effective treatment.

The aim - to analyze the feasibility and methods of determining the state of vegetative status of patients with chronic pancreatitis, which are used in outpatient medicine and scientific practice.

Main part. Chronic diseases of the digestive system, in particular chronic pancreatitis, are widespread in the structure of morbidity of internal organs. Involvement of segmental and suprasegmental vegetative structures in the pathological process significantly complicates the course of chronic pancreatitis, therefore determining the state of the autonomic nervous system and subsequent vegetotropic correction is important to improve the treatment of chronic gastrointestinal pathology in general and chronic pancreatitis in particular.

Conclusion. Determining the state of vegetative state, and especially the presence of autonomic dysfunction in chronic pancreatitis should be the basis for a differentiated approach to regulating the state of the autonomic nervous system, which will lead to more efficient and rational optimization of the functional state of the pancreas and normalization of patients.

KEY WORDS: autonomic nervous system; autonomic dysfunction; chronic pancreatitis; methods of studying autonomic status; heart rate variability.

Отримано 11.02.2021 